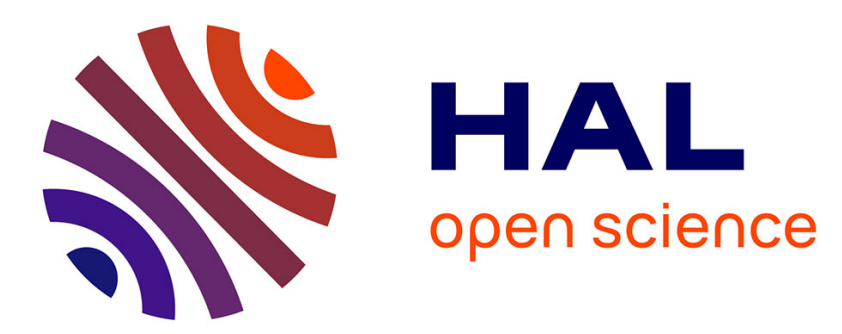

\title{
Pt3MeAu ( $\mathrm{Me}=\mathrm{Ni}, \mathrm{Cu})$ fuel cell nanocatalyst growth, shapes and efficiency: A molecular dynamics simulation approach
}

Pascal Brault, Christophe Coutanceau, Amaël Caillard, Steve Baranton

\section{- To cite this version:}

Pascal Brault, Christophe Coutanceau, Amaël Caillard, Steve Baranton. Pt3MeAu $(\mathrm{Me}=\mathrm{Ni}, \mathrm{Cu})$ fuel cell nanocatalyst growth, shapes and efficiency: A molecular dynamics simulation approach. Journal of Physical Chemistry C, 2019, 123 (49), pp.29656. 10.1021/acs.jpcc.9b06476 . hal-02366886

\section{HAL Id: hal-02366886 https://hal.science/hal-02366886}

Submitted on 16 Nov 2019

HAL is a multi-disciplinary open access archive for the deposit and dissemination of scientific research documents, whether they are published or not. The documents may come from teaching and research institutions in France or abroad, or from public or private research centers.
L'archive ouverte pluridisciplinaire HAL, est destinée au dépôt et à la diffusion de documents scientifiques de niveau recherche, publiés ou non, émanant des établissements d'enseignement et de recherche français ou étrangers, des laboratoires publics ou privés. 
$\mathrm{Pt}_{3} \mathrm{MeAu}(\mathrm{Me}=\mathrm{Ni}, \mathrm{Cu})$ fuel cell nanocatalyst growth, shapes and efficiency: $\mathrm{A}$ molecular dynamics simulation approach

Pascal Brault ${ }^{1}$, Christophe Coutanceau ${ }^{2}$, Amaël Caillard ${ }^{1}$, Stève Baranton ${ }^{2}$

${ }^{1}$ CNRS GREMI, UMR 7344 Université d'Orléans, BP6744, 45067 Orléans cedex 2, France

${ }^{2}$ CNRS IC2MP UMR7285 Université de Poitiers, TSA 51106, 86073 Poitiers cedex 9, France

e-mail:

pascal.brault@univ-orleans.fr

christophe.coutanceau@univ-poitiers.fr

amael.caillard@univ-orleans.fr

steve.baranton@univ-poitiers.fr

Abstract: The formation of the ternary $\mathrm{Pt}_{3} \mathrm{NiAu}$ and $\mathrm{Pt}_{3} \mathrm{CuAu}$ nanostructures are examined using molecular dynamics simulations in the context of free (i.e. unsupported) cluster growth in an unreactive atmosphere. The role of Au segregation towards the cluster surface on the final composition and structure of the nanoparticles is highlighted, as well as the effect of temperature on the growth and structure of the ternary nanocatalysts. Indeed, while a $\mathrm{Pt}_{3} \mathrm{NiAu}$ nanoparticle consisted in core of $\mathrm{Pt}_{3} \mathrm{Ni}$ alloy surrounded by an $\mathrm{Au}$ sub-monolayer, $\mathrm{a}$ $\mathrm{Pt}_{3} \mathrm{CuAu}$ particle consisted in a $\mathrm{Pt}_{\mathrm{x}} \mathrm{Cu}$ core alloy $(\mathrm{x}<3)$ surrounded by a sub-monolayer of $\mathrm{AuCu}$ alloy. The predicted atomic structures are enlightening the experimental results obtained from low temperature syntheses of ternary nanomaterials and their electrochemical behaviors.

Keywords: Fuel cell nanocatalyst; molecular dynamics; plasma sputtering; electrochemical characterization 


\section{Introduction}

The activation of oxygen is of paramount importance for electrocatalytic processes in general and for fuel cells in particular to make this technology marketable. Because the oxygen reduction reaction (ORR) is occurring at the cathode of fuel cells with very low kinetics, it has been extensively studied for the last fifty years with the aim at enhancing the catalyst and cathode efficiencies [1]. Controlling the metal nanoparticle growth is essential for improving particle size distribution, structure, morphology and, in the case of multi-metallic catalysts, surface composition to further achieve high activity and selectivity. To obtain this control, the understanding of the nanoparticle growth mechanism is a prerequisite.

It is indeed known that platinum-based ternary alloys are excellent catalysts for the electroreduction reaction of oxygen molecule, which occurs at the cathode of a PEMFC (proton exchange membrane fuel cell) [2-10]. Beyond the lowering of the platinum loading in the electrode catalytic layers, alloyed Pt-based materials display an improved catalytic activity towards the ORR [11], a better tolerance towards poisoning species $[12,13]$ and, for some authors, an enhanced durability under fuel cell working conditions [14]. Addition of Au was indeed proposed to improve the durability of Pt-based nanocatalysts [14-23]. Nevertheless, only few fundamental studies on such kind of catalysts are available.

The present work aims at calculating and discussing the growth mechanism of such ternary catalysts in order to predict their compositions and morphologies for direct comparison with nanocatalysts synthesized by classical low temperature methods (wet chemistry or low temperature plasma deposition). This dynamical point of view is intended to unravel the variety (or not) of the generated nanoclusters and to clarify the link between nanocluster composition, structure, morphology and electrochemical behaviors. 
To this end, molecular dynamics (MD) simulations are suitable ways for addressing the growth mechanism of nanoclusters, and especially nanocatalysts [24]. This simulation method consists in calculating all the trajectories in a group of interacting atoms with only a restricted number of assumptions: only the interaction forces and a set of initial conditions preferably matching the experimental conditions are required.

In a previous work, we have been able to link results from DFT calculations and MD simulations concerning the growth and structure of ternary catalysts based only on noble metals ( $\mathrm{Pt}_{\mathrm{x}} \mathrm{Pd}_{\mathrm{y}} \mathrm{Au}_{\mathrm{z}}$ materials) [20]. In the present work, molecular dynamics simulations will be use to predict the growth mechanism and the final structure of $\mathrm{Pt}_{3} \mathrm{Me}$ and $\mathrm{Pt}_{3} \mathrm{AuMe}$ catalysts, where Me corresponds to a non-noble metal. Indeed, there is no evidence that same results could be a priori obtained by replacing a noble metal ( $\mathrm{Pd}$ ) by a non-noble one. The formations of ternary $\mathrm{Pt}_{3} \mathrm{NiAu}$ and $\mathrm{Pt}_{3} \mathrm{CuAu}$ materials are considered since they are well documented. $\mathrm{Pt}_{3} \mathrm{Ni}$, as a base bimetallic alloy [25-28], and $\mathrm{Pt}_{3} \mathrm{NiAu}$ ternary system [21] exhibit very high initial electrocatalytic activity towards the ORR, whereas $\mathrm{Pt}_{3} \mathrm{CuAu}$ ternary system displays higher stability [21].

Section 2 will present the simulation method and describe the chosen parameters, while section 3 will present, compare and discuss molecular dynamics results in light of experimental ones, with a special focus on electrochemical results in terms of activity towards ORR and surface nanoparticles composition changes with ageing. [22].

\section{Methods}

For simulating free (i.e. unsupported) clustering, atoms are randomly distributed in a cubic box with atomic ratios corresponding to the targeted composition. A neutral gas buffer is added for describing the energy dissipation during collisions. This is mimicking free nanoparticle growth in the context of a gas aggregation source (GAS) where atoms are 
sputtered in such a gas at a pressure high enough for allowing clustering in the flight [29-33]. This approach is also likely mimicking the nanoparticle growth in a liquid, as it is the case for wet chemistry synthesis such as the "water in oil" microemulsion method, where the reaction takes place in water nanodroplets containing the metal salts in concentrations corresponding to the targeted compositions of nanoparticles. In this latter case, the ratio between the metal atom number and the liquid molecule number is smaller than the ratio between the metal atom number and the gas atom number in the case of simulation experiment.

In the present work, the atomic vapor consists in $\mathrm{Pt}, \mathrm{Au}$ and $\mathrm{Me}(\mathrm{Ni}$ or $\mathrm{Cu}$ ) atoms or $\mathrm{Pt}$ and Me (Ni or $\mathrm{Cu}$ ) immersed in an Argon bath, dedicated to the dilution of metal atoms and to the dissipation of the energy generated during bond formation. The simulation box has a size of $64 \times 64 \times 64 \mathrm{~nm}^{3}$ and is filled with $\mathrm{N}_{\mathrm{Ar}}=128000, \mathrm{~N}_{\mathrm{Pt}}=19200, \mathrm{~N}_{\mathrm{Me}}=6400$ and $\mathrm{N}_{\mathrm{Au}}=6400$ atoms. Periodic boundary conditions are applied in the $x, y, z$ directions. Initial temperature is $300 \mathrm{~K}$. The equations of motion used for describing the clustering process is:

$$
\frac{\partial^{2} \vec{r}_{i}(\mathrm{t})}{\partial t^{2}}=\frac{1}{m_{\mathrm{i}}} \vec{f}_{\mathrm{i}}, \quad \text { with the force } \vec{f}_{\mathrm{i}}=-\frac{\partial}{\partial \vec{r}} \mathrm{~V}\left(\vec{r}_{1}(t), \vec{r}_{2}(t), \cdots, \vec{r}_{\mathrm{N}}(t)\right)
$$

where $\vec{r}_{i}(\mathrm{t})$ is the instantaneous position of atom i with mass $m_{\mathrm{i}}$ at time $t$, and $\mathrm{V}$ is the interaction potential function.

Embedded Atom Model (EAM) potential functions [34-36] are suitable for describing metal atom interactions, i.e. $\mathrm{Pt}, \mathrm{Me}(\mathrm{Ni}$ or $\mathrm{Cu})$ and $\mathrm{Au}$ in the present case. The EAM potential is a many-body potential which is including the collective motions of electrons. Essentially, each atom contributes to the overall charge density of the system, via a spherical electron charge, centered at its nucleus. The binding between atoms is modelled considering that these atoms are embedded in this "pool" of charge, where the energy gained by embedding an atom at location $r$ is a function of the local electron density.

The EAM potential energy $E_{p o t}$ of the system thus reads as: 


$$
E_{p o t}=\sum_{\mathrm{i}=1}^{\mathrm{N}} E_{\mathrm{i}}=\frac{1}{2} \sum_{\mathrm{i}=1}^{\mathrm{N}} \sum_{\mathrm{j}, \mathrm{j} \neq \mathrm{i}}^{\mathrm{N}} \varphi_{\mathrm{ij}}\left(r_{\mathrm{ij}}\right)+\sum_{\mathrm{i}=1}^{\mathrm{N}} \mathrm{F}_{\mathrm{i}}\left(\rho_{\mathrm{i}}\right)
$$

where $E_{i}$ is the potential energy of an atom $\mathrm{i}, \varphi\left(r_{\mathrm{ij}}\right)$ is the pair energy term as a function of the interatomic separation $r_{i j}$ between atoms $i$ and $j$, and $F_{i}\left(\rho_{i}\right)$ is the many-body embedding energy term, function of the local electron density, $\rho_{\mathrm{i}}$, at the position of atom $\mathrm{i}$.

The local electron density is calculated as:

$$
\rho_{\mathrm{i}}=\sum_{\mathrm{j}, \mathrm{j} \neq \mathrm{i}}^{\mathrm{N}} \mathrm{f}_{\mathrm{j}}\left(r_{\mathrm{ij}}\right)
$$

where $\mathrm{f}_{\mathrm{j}}\left(r_{\mathrm{ij}}\right)$ is the contribution from atom $\mathrm{j}$ to the electron density at the site of the atom $\mathrm{i}$.

The pair potential energy term is defined as:

$$
\varphi(r)=\frac{\operatorname{Aexp}\left[-\alpha\left(\frac{r}{r_{\mathrm{e}}}-1\right)\right]}{1+\left(\frac{r}{r_{\mathrm{e}}}-\kappa\right)^{20}}-\frac{\operatorname{Bexp}\left[-\beta\left(\frac{r}{r_{\mathrm{e}}}-1\right)\right]}{1+\left(\frac{r}{r_{\mathrm{e}}}-\lambda\right)^{20}}
$$

where $r_{\mathrm{e}}$ is the equilibrium spacing between nearest neighbors, $A, B, \alpha$, and $\beta$ are four adjustable parameters, and $\mathrm{k}$ and $\lambda$ are two additional parameters for the cutoff distances [35, 36]. The electron density function is taken to have the same form as the attractive term in the pair potential with the same values.

The electron density function is given by:

$$
\mathrm{f}(r)=\frac{\mathrm{f}_{\mathrm{e}} \exp \left[-\beta\left(\frac{r}{r_{\mathrm{e}}}-1\right)\right]}{1+\left(\frac{r}{r_{\mathrm{e}}}-\lambda\right)^{20}}
$$

The pair potential between atoms of two different elements ( $a$ and $b$ ) is built using the mixing rule [37]:

$$
\varphi^{\mathrm{ab}}(r)=\frac{1}{2}\left[\frac{\mathrm{f}^{\mathrm{b}}(r)}{\mathrm{f}^{\mathrm{a}}(r)} \varphi^{\mathrm{aa}}(r)+\frac{\mathrm{f}^{\mathrm{a}}(r)}{\mathrm{f}^{\mathrm{b}}(r)} \varphi^{\mathrm{bb}}(r)\right]
$$

The embedding energy function $\mathrm{F}(\rho)$ is represented by three equations defining it in different electron density ranges and having matching values and slopes at the two junctions: 


$$
\begin{aligned}
& \mathrm{F}(\rho)=\sum_{\mathrm{i}=0}^{3} \mathrm{~F}_{\mathrm{ni}}\left(\frac{\rho}{0.85 \rho_{\mathrm{e}}}-1\right)^{\mathrm{i}}, \quad \rho<0.85 \rho_{\mathrm{e}} \\
& \mathrm{F}(\rho)=\sum_{\mathrm{i}=0}^{3} \mathrm{~F}_{\mathrm{i}}\left(\frac{\rho}{\rho_{\mathrm{e}}}-1\right)^{\mathrm{i}}, \quad 0.85 \rho_{\mathrm{e}} \leq \rho<1.15 \rho_{\mathrm{e}} \\
& \mathrm{F}(\rho)=\mathrm{F}_{\mathrm{e}}\left[1-\eta \ln \left(\frac{\rho}{\rho_{\mathrm{e}}}\right)\right] \times\left(\frac{\rho}{\rho_{\mathrm{e}}}\right)^{\eta}, \quad \rho \geq 1.15 \rho_{\mathrm{e}}
\end{aligned}
$$

where $\eta, \mathrm{F}_{\mathrm{i}}, \mathrm{F}_{\mathrm{ni}}, \mathrm{F}_{\mathrm{e}}, \rho_{\mathrm{e}}$ are adjustable EAM parameters $[35,36]$.

Ar atoms are interacting with metal atoms through repulsive Molière potentials [38]. Initial velocities of all atoms are sampled from a Maxwell-Boltzmann distribution at $300 \mathrm{~K}$. Calculations consider a constant number of metal atoms, constant volume and constant total energy (NVE ensemble). This allows calculating the interaction between metal atoms without any constraints. NVT ensemble (for which the temperature of Ar atoms is maintained constant) calculation is chosen for mimicking cluster cooling via Ar collisions on clusters, as it occurs in experiments. The time step for integrating the equation (1) is set to $1 \mathrm{fs}$ and $40 \mathrm{~ns}$ total simulated time. Simulations have been carried out using the Large-scale Atomic/Molecular Massively Parallel Simulator (LAMMPS) $[39,40]$ and visualization using the Visual Molecular Dynamics (VMD) program [41,42].

\section{Results}

\section{1 $\quad \mathrm{Pt}_{3} \mathrm{Ni}(+\mathrm{Au})$ growth}

Figure 1a,c (full simulation box) display the snapshots from the simulations for the $\mathrm{Pt}_{3} \mathrm{NiAu}$ free nanocatalyst growth at 20 ns and 40 ns simulation time, respectively, when the cluster coalescence is already well advanced. Two typical sizes are observed in Figure $1 \mathrm{a}$, and this is confirmed by the corresponding nearly bimodal size distribution presented in Figure $1 \mathrm{~b}$. The two cluster families have mean diameters of 1.8 and $3.0 \mathrm{~nm}$ indicating that coalescence of smaller clusters with similar size has already started. At the latter step (40 ns), the cluster 
density is low enough for avoiding further significant coalescence of clusters. The size distribution remains bimodal, is broadened and shifted to larger sizes. The two cluster families are centered at diameters of 2.6 and $3.8 \mathrm{~nm}$, respectively.


Figure 1: Snapshots of $\mathrm{Pt}_{3} \mathrm{NiAu}$ at different simulation times a) $\mathrm{t}=20 \mathrm{~ns}$ and c) at $\mathrm{t}=40 \mathrm{~ns}$. The corresponding size distributions are reported in graphs $b$ ) and d). Pt atoms are blue, Ni atoms brown, and Au atoms pink. Argon atoms are not displayed for clarity. Colors only online.

It is clearly visible that Au atoms predominantly cover the nanoparticle surface, indicating the Au segregation towards surface is a major mechanism for the growth of such multimetallic catalysts. For comparison, Figure 2 displays $\mathrm{Pt}_{3} \mathrm{Ni}$ snaphots and corresponding 
diameter distributions for $\mathrm{t}=20 \mathrm{~ns}$ (Figure $2 \mathrm{a}, \mathrm{b}$ ) and $40 \mathrm{~ns}$ (Figure $2 \mathrm{c}, \mathrm{d}$ ) simulation times. In the case of $\mathrm{Pt}_{3} \mathrm{Ni}$ cluster growth simulation, the simulations conditions considers a box with a size of $64 \times 64 \times 64 \mathrm{~nm}^{3}$ filled with $\mathrm{N}_{\mathrm{Ar}}=128000, \mathrm{~N}_{\mathrm{Pt}}=19200, \mathrm{~N}_{\mathrm{Ni}}=6400$.
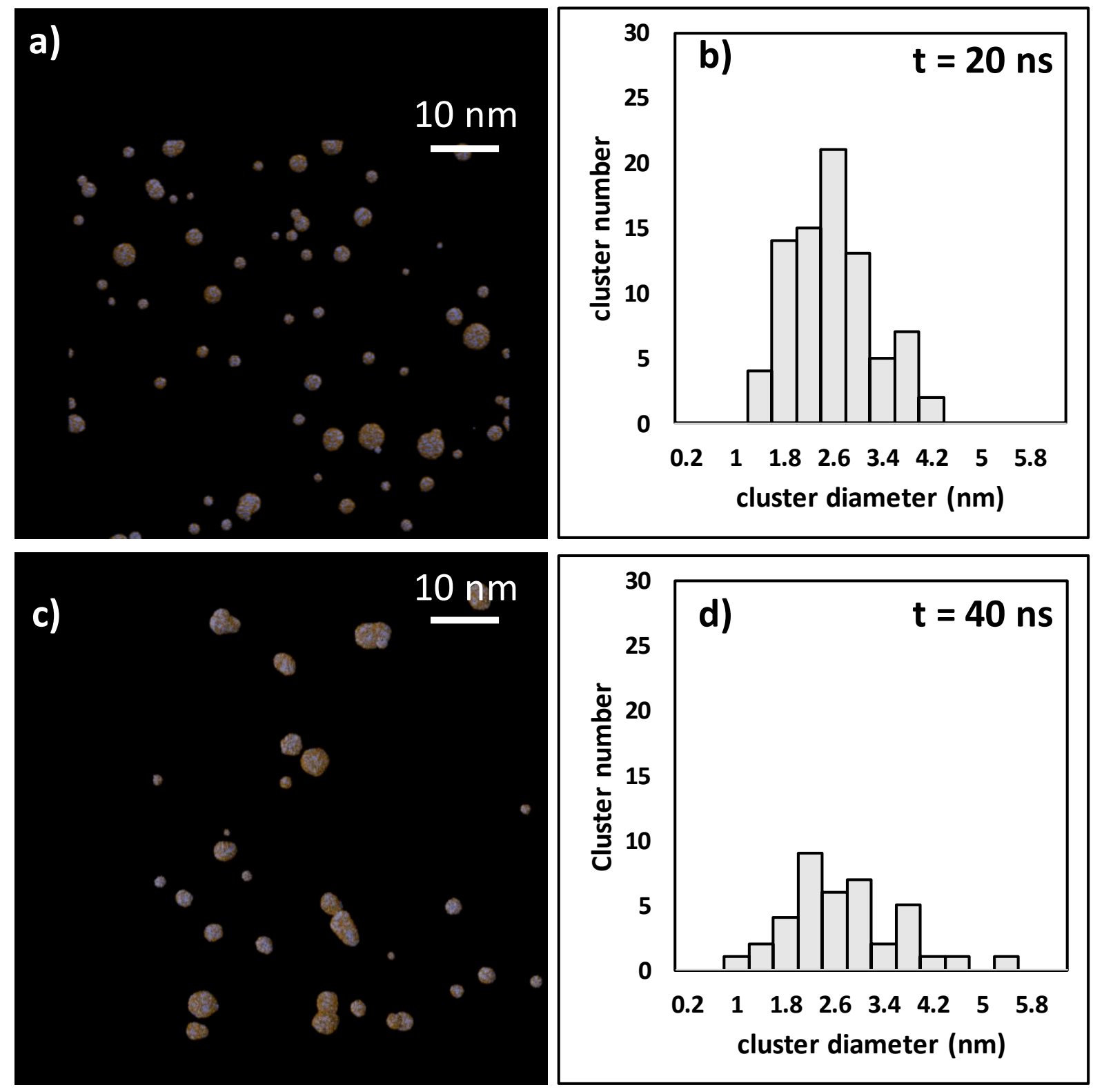

Figure 2: Snapshots of $\mathrm{Pt}_{3} \mathrm{Ni}$ at different simulation times a) $\mathrm{t}=20 \mathrm{~ns}$ and c) at $\mathrm{t}=40 \mathrm{~ns}$. The corresponding size distributions are reported in graphs b) and d). Pt atoms are blue and $\mathrm{Ni}$ atoms brown. Argon atoms are not displayed for clarity. Colors only online.

Figure 2 shows that the growth of $\mathrm{Pt}_{3} \mathrm{Ni}$ clusters is very similar to that of the $\mathrm{Pt}_{3} \mathrm{NiAu}$ ones. Nevertheless the size distribution at $20 \mathrm{~ns}$ appears narrower for $\mathrm{Pt}_{3} \mathrm{Ni}$ than for $\mathrm{Pt}_{3} \mathrm{NiAu}$. When looking to the change of the mean diameter with respect to time (Figure 3), the $\mathrm{Pt}_{3} \mathrm{Ni}$ mean 
diameter is always slightly smaller than that of $\mathrm{Pt}_{3} \mathrm{NiAu}$. The difference comes from the additional $\mathrm{Au}$ atoms ( $25 \%$ more atoms in the initial vapor compared with the case of $\mathrm{Pt}_{3} \mathrm{Ni}$ ) leading to larger particles and also to the different numbers of clusters formed. Indeed, less metal atoms are involved in the $\mathrm{Pt}_{3} \mathrm{Ni}$ cluster growth simulation than in the $\mathrm{Pt}_{3} \mathrm{NiAu}$ cluster growth simulation, therefore, there is no reason for the number of clusters formed at a given time to be the same in both cases. The similar diameter values at $40 \mathrm{~ns}$ can originate from lower statistics since the growth and then the coalescence of clusters involves a decrease of their number with time. The size distributions of $\mathrm{Pt}_{3} \mathrm{NiAu}$ and $\mathrm{Pt}_{3} \mathrm{Ni}$ clusters for calculating the mean diameters at different simulation times are given in supplementary information (Figure S1).

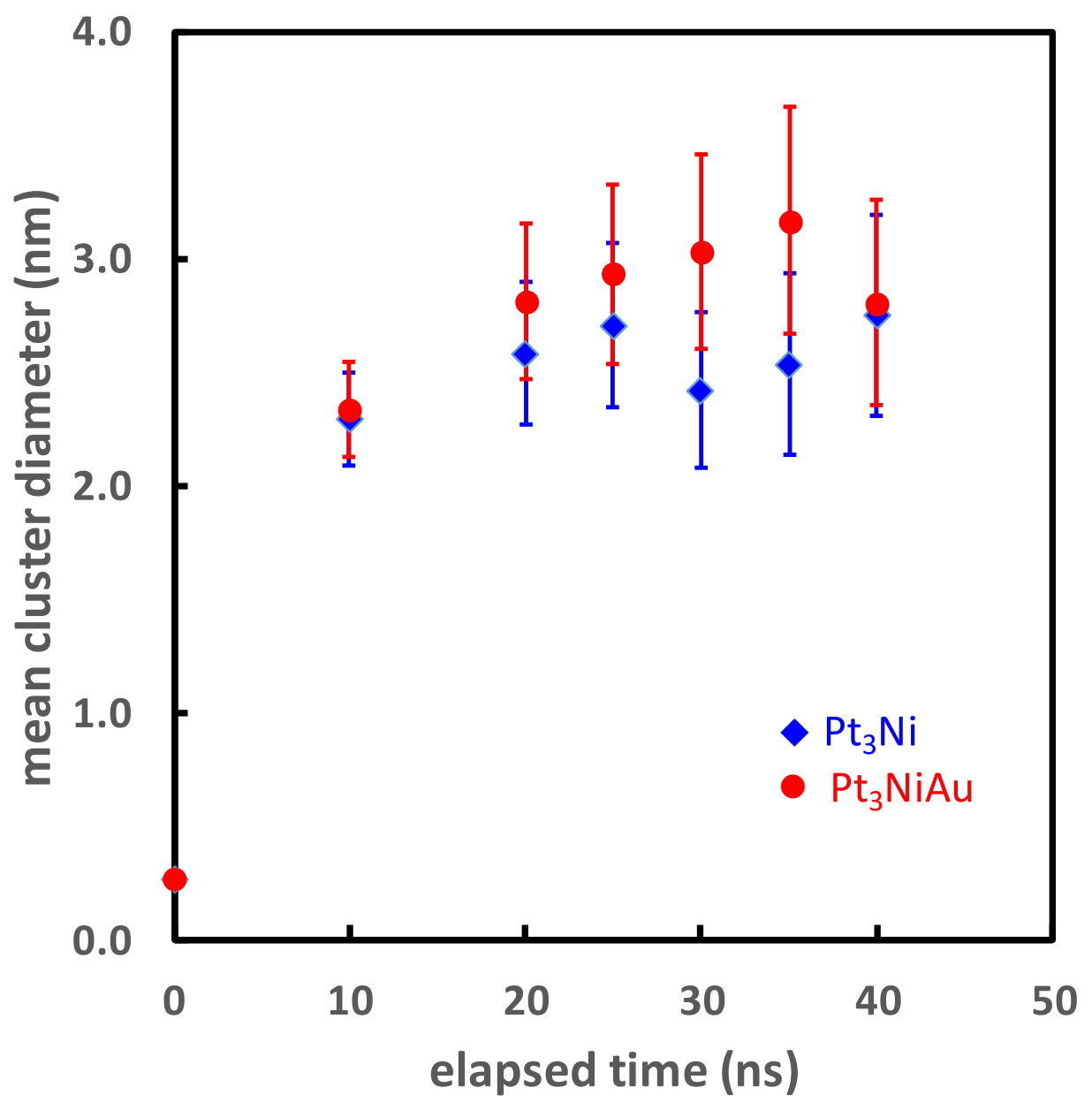


Figure 3: $\mathrm{Pt}_{3} \mathrm{Ni}(\diamond)$ and $\mathrm{Pt}_{3} \mathrm{NiAu}(\bullet)$ cluster mean diameters along simulation time. The error bars are calculated assuming the error comes from cluster statistics. The decrease of cluster number for larger times implies higher uncertainty (larger error bars). Color only online

The progress of the cluster coalescence process at $40 \mathrm{~ns}$ is depicted in Figure $4 \mathrm{~b}$ for $\mathrm{t}=40$ ns, where the proportion of small clusters has decreased in comparison with that in Figure 1a. The histogram presented in Figure $1 \mathrm{~d}$ shows a shift towards higher cluster sizes and a broadening of the corresponding size distribution. Due to coalescence, clusters present first peanut-like shapes in the early stage of coalescence, and evolve towards spherical shapes further into the coalescence process.

Figure 4: Zoomed snapshots of $\mathrm{Pt}_{3} \mathrm{NiAu}$ at a) $\left.\mathrm{t}=20 \mathrm{~ns}, \mathrm{~b}\right)$ at $\mathrm{t}=40 \mathrm{~ns}$. Cross section of typical clusters at c) $t=20 \mathrm{~ns}$ and d) $\mathrm{t}=40 \mathrm{~ns}$. A well and a less crystallized clusters are displayed. Pt atoms are blue, Ni brown, and Au pink. Argon atoms are not displayed for clarity. Colors only online.

$\mathrm{Pt}_{3} \mathrm{NiAu}$ clusters at 20 ns mainly exhibit spherical not fully crystallized clusters (Figure 4a). Au atoms are only present on the surface (Figure 4c) and do not fully cover the nanoparticle surface leaving open access to the core catalytic sites.

Figure $4 b$ provides a zoom at 40 ns. The clusters have mainly kept their spherical shape during coalescence. Some of them (not shown on Figure 4b) have a peanut shape. Looking at the clusters cross-section (Figure $4 d$ ), the peanut shaped nanoparticles exhibit a well crystallized core while spherical ones remains not fully crystallized. 



Figure 5: Zoomed snapshots of $\mathrm{Pt}_{3} \mathrm{Ni}$ at a) $\left.\mathrm{t}=2 \mathrm{nns}, \mathrm{b}\right)$ at $\mathrm{t}=40$ ns. Cross section of typical clusters at c) $t=20 \mathrm{~ns}$ and $d$ ) $t=40 \mathrm{~ns}$. A well and a less crystallized clusters are displayed. Pt atoms are blue and Ni brown. Argon atoms are not displayed for clarity. Colors only online.

Figure 5 displays zoom of $\mathrm{Pt}_{3} \mathrm{Ni}$ clusters at $\mathrm{t}=20$ and $\mathrm{t}=40 \mathrm{~ns}$ and a cross section of typical $\mathrm{Pt}_{3} \mathrm{Ni}$ clusters. They are identical to the $\mathrm{Pt}_{3} \mathrm{Ni}$ core of $\mathrm{Pt}_{3} \mathrm{NiAu}$. This means that the $\mathrm{Au}$ segregation towards cluster outer surface does not affect the $\mathrm{Pt}_{3} \mathrm{Ni}$ core.

Concerning $\mathrm{Pt}_{3} \mathrm{NiAu}$ cluster composition, it is worth to note that the individual cluster composition calculated from snapshot data of Figure 1 , is close to the $\mathrm{Pt}_{3} \mathrm{NiAu}$ nominal one (with a standard deviation within $10 \%$ at $t=20 \mathrm{~ns}$ and within $6 \%$ at $\mathrm{t}=40 \mathrm{~ns}$ ). All clusters 
display systematically a $\mathrm{Pt}_{3} \mathrm{Ni}$ crystalline core structure, similar to the one obtained without $\mathrm{Au}$, with an Au sub-monolayer covering this core structure as shown in cross-sections of Figures $2 \mathrm{c}$ and $2 \mathrm{~d}$. This is consistent with the very lower surface energy of Au compared to those of Pt and $\mathrm{Ni}$ as determined experimentally [43], as well as from theoretically determined EAM interaction potentials (table 1). It was previously shown that Pt surface atoms remain accessible for $\mathrm{Pt}_{\mathrm{x}} \mathrm{Pd}_{\mathrm{y}} \mathrm{Au}$ catalysts [18] with $\mathrm{Au}$ atomic ratio lower than 25 at\%; this is also confirmed for $\mathrm{Pt}_{3} \mathrm{NiAu}$ with $\mathrm{Au}$ atomic ratio of 20 at\%, as Pt surface atoms can be observed on snapshots in Figures $2 a$ and $2 b$.

\section{2 $\quad \mathrm{Pt}_{3} \mathrm{Cu}(+\mathrm{Au})$ growth}

$\mathrm{MD}$ simulations were also carried out for the growth of $\mathrm{Pt}_{3} \mathrm{CuAu}$ and $\mathrm{Pt}_{3} \mathrm{Cu}$ under the same conditions as for $\mathrm{Pt}_{3} \mathrm{NiAu}$. Figure 6 provides a zoom at $40 \mathrm{~ns}$ on $\mathrm{Pt}_{3} \mathrm{CuAu}$ typical clusters. At this stage, there is peanut-like and spherical-like nanoparticles. As in the case of $\mathrm{Pt}_{3} \mathrm{NiAu}$ nanoparticles, the formation of a core PtCu alloy is predicted, as well as the segregation of $\mathrm{Au}$ to the surface of nanoparticles (no PtAu alloy formation). But, the main important information is that MD simulations predict the formation of $\mathrm{AuCu}$ alloys on the surface of the $\mathrm{Pt}_{3} \mathrm{CuAu}$ nanoparticles, which is not the case with $\mathrm{Pt}_{3} \mathrm{NiAu}$ material. Moreover, contrary to $\mathrm{Pt}_{3} \mathrm{NiAu}$, $\mathrm{Pt}_{3} \mathrm{CuAu}$ are well crystallized. Cuboctahedron are present as well as structure s corresponding to two partially coalesced cuboctahedrons leading to peanut like shapes. Snapshots at $20 \mathrm{~ns}$

and 40 ns as well as corresponding size distributions for $\mathrm{Pt}_{3} \mathrm{CuAu}$ and $\mathrm{Pt}_{3} \mathrm{Cu}$ are presented in Figures S2 and S3 of supporting information, respectively. 




Figure 6: Typical $\mathrm{Pt}_{3} \mathrm{CuAu}$ nanoparticles at $\mathrm{t}=40 \mathrm{~ns}$. a) Surface structure, b) cross-section. $\mathrm{Pt}$ atoms are blue, $\mathrm{Cu}$ tan, and Au pink. Argon atoms are not displayed for clarity. Colors only online.

Figure 7 provides the corresponding zoom of $\mathrm{Pt}_{3} \mathrm{Cu}$ at 40 ns. The $\mathrm{Pt}_{3} \mathrm{Cu}$ nanoparticle structures are identical to the structure of the $\mathrm{Pt}_{3} \mathrm{Cu}$ core of $\mathrm{Pt}_{3} \mathrm{CuAu}$ core. Moreover, $\mathrm{Cu}$ segregation towards the Pt surface is clearly visible. This makes surface Au alloying with $\mathrm{Cu}$ likely to occur. 




Figure 7: Typical $\mathrm{Pt}_{3} \mathrm{Cu}$ nanoparticles at $\mathrm{t}=40 \mathrm{~ns}$. a) Surface structure, b) cross-section. Pt atoms are blue and $\mathrm{Cu}$ tan. Argon atoms are not displayed for clarity. Colors only online.

The differences observed in the structures of $\mathrm{Pt}_{3} \mathrm{NiCu}$ and $\mathrm{Pt}_{3} \mathrm{CuAu}, \mathrm{Pt}_{3} \mathrm{Ni}$ and $\mathrm{Pt}_{3} \mathrm{Cu}$, are due to the different surface energies (table 1). The surface energy for $\mathrm{Cu}$ is lower than that for $\mathrm{Ni}$ and not so far from that for $\mathrm{Au}$. So surface alloying of $\mathrm{AuCu}$ is expected, while $\mathrm{Cu}$ segregation to Pt surface is likely to occur, but to less extend than for Au. Moreover, EAM potentials include electronic interactions which also play a role in the clustering process. It is thus interesting to note here that $\mathrm{Ni}$ and $\mathrm{Cu}$ behave differently in the growth process of multimetallic nanoparticles. 
Table 1: Experimental [43] and EAM deduced surface energies [34] in $\mathrm{Jm}^{-2}$.

\begin{tabular}{lcccc}
\hline & Pt & $\mathrm{Ni}$ & $\mathrm{Cu}$ & $\mathrm{Au}$ \\
\hline EAM (111) face & 1.44 & 1.45 & 1.17 & 0.79 \\
EAM (100) face & 1.650 & 1.58 & 1.28 & 0.92 \\
EAM (110) face & 1.750 & 1.73 & 1.40 & 0.98 \\
$\begin{array}{l}\text { Experimental } \\
\text { (average face) }\end{array}$ & 2.49 & 2.38 & 1.79 & 1.50 \\
\hline
\end{tabular}

\section{Discussion}

Mattei et al. [44] used gas-phase technique such as gas aggregation source (also called low energy cluster beam deposition) for the synthesis of Au-Pt-Pd ternary systems (to provide active sites for enhanced catalytic activity) and investigated the parameters that govern the nucleation and growth of each element into monometallic clusters and alloy nanoparticles by means of classical MD simulations. In agreement with theoretical calculations, they observed that the element having the lower energy very often tends to segregate at the surface even without post annealing. The trends were then a segregation of Pt atoms to the core of NPs whereas $\mathrm{Au}$ atoms tended to segregate to the surface and to create a single-layer envelope surrounding the particles. These experimental and theoretical results are in full agreement with those presented in this article for $\mathrm{Pt}_{3} \mathrm{NiAu}$ and $\mathrm{Pt}_{3} \mathrm{CuAu}$ nanomaterials.

The phase diagrams of the Ni-Pt and Cu-Pt systems clearly indicate that the formations of defined $\mathrm{Pt}_{3} \mathrm{Ni}$ and $\mathrm{Pt}_{3} \mathrm{Cu}$ alloy phases are possible at low temperatures $[45,46]$, and the syntheses of $\mathrm{Pt}_{x} \mathrm{Ni}_{10-\mathrm{x}}$ and $\mathrm{Pt}_{\mathrm{x}} \mathrm{Cu}_{10-\mathrm{x}}$ alloys were already performed by wet chemistry at room temperature $[21,47-49]$. Then, the formations of the PtNi and PtCu alloys predicted by MD simulations are consistent with experimental results. 
The second important prediction of $\mathrm{MD}$ simulation concerns the formation of $\mathrm{Au}_{\mathrm{y}} \mathrm{Cu}_{1-y}$ alloy at the surface of the nanoparticles, whereas AuNi alloys are not formed. This prediction agrees with studies on AuCu and AuNi phase diagrams showing that the Cu-Au system forms ordered compounds whereas $\mathrm{Ni}$-Au system forms phase-separate compounds [50]. Indeed, for atomic ratio of 1:1, as it is the case in the present study, the formation of AuCu alloy can occur in a temperature range from ca. $0{ }^{\circ} \mathrm{C}$ to ca. $400{ }^{\circ} \mathrm{C}$ [51]. For AuNi, the formation of a FCC alloy phase occurs only at very high temperatures, i.e. higher than $900 \mathrm{~K}$; at lower temperature, separate Ni-rich FCC and Au-rich FCC structures coexist [50,52].

The third important prediction from the MD simulations is that gold atoms are segregating towards the surface of the nanoparticles forming a sub-monolayer. This result agrees with the fact that Pt and Au are not or very slightly miscible at low temperatures. Indeed, according to the Pt-Au phase diagram proposed by Okamoto and Massalski [53], for an atomic ratio of $20 \%$ in gold as in the case studied in this paper, the minimum temperature for the formation of a Pt-Au alloy is higher than $900 \mathrm{~K}$. Although the synthesis of materials at the nanoscopic level may help to decrease the alloying temperature, it is expected that Pt and Au phase segregation occurs at the temperature considered in the present work (300 K), in agreement with MDs simulations.

At first glance, the formation of metastable state, as homogeneous Pt-Au nano-alloys or Pt@Au nanoparticles, are generally difficult to achieve, or even impossible, by conventional synthesis techniques. Pt-Au nano-alloys are generally synthesized by complex chemical methods involving at the end of the synthesis processes high temperature treatments [54, 55], whereas the formation of NPs where Au is placed in the NPs core can be obtained by using GAS when Au is sputtered with Ag or Co in specific conditions [56]. 
However, a simple wet chemistry synthesis method allows producing Pt-Au alloys over a large Pt/Au atomic ratio range, without any thermal treatment. Indeed, the "water in oil" microemulsion method has been used for this purpose [22, 57], although no theoretical information was given to explain this unexpected result. Yet, Lankiang et al. [22] have shown that these Pt-Au alloys (and $\mathrm{Pt}_{3} \mathrm{NiAu}$ ) underwent gold enrichment of their surfaces under electrochemical stress (potential cycles between $0.6 \mathrm{~V}$ and $1.05 \mathrm{~V}$ [21] or $1.25 \mathrm{~V}$ vs. RHE [22]). This enrichment was shown to be responsible of the decrease of the activity towards ORR, gold being much less active than platinum for this reaction. Because the electrode potential is directly related to the energy exchange $(\Delta G+\mathrm{nF} \Delta E=0)$, the phase segregation (segregation of gold atoms from the bulk of nanoparticles towards their surface) translates into a low stability of the alloyed PtAu nanoparticles which tends towards the formation of a core shell structure, in agreement with previous theoretical studies based on molecular dynamics simulations [58], Monte-Carlo simulations [59] and density functional studies $[19,60]$. These results also confirm those of our MDs simulations showing that $A u$ atoms preferentially segregate at the ternary $\mathrm{Pt}_{3} \mathrm{NiAu}$ nanoparticles.

In the case of $\mathrm{Pt}_{3} \mathrm{CuAu}$ material, the nanoparticle surface did not undergo gold enrichment, and it was shown that these catalysts were more stable upon potential cycling than $\mathrm{Pt}_{3} \mathrm{NiAu}$ [21]. This can be explained by the formation of an AuCu alloy close to the nanoparticle surface, as predicted by the MD simulations in the present work, as well as by DFT calculations by Jennings et al. [61]. These last authors concluded indeed that core atoms such as Cu having preferential bonding to Au will improve the stability of the nanoparticle. 


\section{Conclusion}

Molecular dynamics simulations have been carried out for describing the growth process of free (unsupported) $\mathrm{Pt}_{3} \mathrm{NiAu}$ and $\mathrm{Pt}_{3} \mathrm{CuAu}$ nanocatalysts. Starting from an initial random metal vapor immersed in a buffer argon gas, the cluster growth is evolving with systematic core shell structure, with Au being segregated at the surface of the nanoparticles. At all steps of the simulations, $\mathrm{Pt}_{3} \mathrm{Ni}$ and $\mathrm{Pt}_{\mathrm{x}} \mathrm{Cu}(\mathrm{x}<3)$ bulk alloys are formed, consistently with $\mathrm{Pt}_{3} \mathrm{Ni}$ and $\mathrm{Pt}_{3} \mathrm{Cu}$ growth in identical conditions. An important difference between both systems is the formation of an AuCu alloy at the surface of the $\mathrm{Pt}_{3} \mathrm{CuAu}$ nanoparticles, whereas in the case of $\mathrm{Pt}_{3} \mathrm{NiAu}$ the formation of an AuNi alloy is not predicted. The vapor/cluster temperature evolution is revealing the different steps, nucleation, aggregation and coalescence of the nanocatalyst growth. The growth, composition and structure are consistent with previous finding on low temperature synthesis methods by wet chemistry and gas-phase technique such as gas aggregation source. Although the "water in oil" microemulsion method allowed synthesizing PtAu alloys, accelerated aging tests under potential cycling of $\mathrm{Pt}_{3} \mathrm{NiAu}$ led to segregation of gold at the nanoparticle surface pointing out the low stability of PtAu alloys. In contrary, in the case of $\mathrm{Pt}_{3} \mathrm{CuAu}$ catalyst, accelerated aging tests didn't led to gold surface enrichment of the particles and the stability of the catalyst was enhanced. This is likely related to the formation of the AuCu alloy at the surface of nanoparticles that stabilizes them and avoid the gold segregation to the surface. The convergence between MDs, DFT and experimental results gives a consistent picture for linking electrochemical behavior with structure and composition of $\mathrm{Pt}_{3} \mathrm{NiAu}$ and $\mathrm{Pt}_{3} \mathrm{CuAu}$ nanocatalysts.

\section{Conflicts of interest}

There are no conflicts to declare 
Acknowledgements: The research leading to these results has received funding from the European Union's Seventh Framework Programme (FP7/2007-2013) for the Fuel Cells and Hydrogen Joint Technological Initiative under grant agreement \#325327 (SMARTCat project)

\section{Supplementary information}

Figure S1: a) $\mathrm{Pt}_{3} \mathrm{NiAu}$ size distributions at 10, 20, 25, 30, 35 and $\left.40 \mathrm{~ns}, \mathrm{~b}\right) \mathrm{Pt}_{3} \mathrm{Ni}$ size distributions at 10, 20, 25, 30, 35 and $40 \mathrm{~ns}$

Figure S2: Snapshots of $\mathrm{Pt}_{3} \mathrm{CuAu}$ at different simulation times a) $\mathrm{t}=20 \mathrm{~ns}$ and c) at $\mathrm{t}=40 \mathrm{~ns}$. The corresponding size distributions are reported in graphs b) and d). Pt atoms are blue, $\mathrm{Cu}$ atoms tan, and Au atoms pink. Argon atoms are not displayed for clarity.

Figure S3: Snapshots of $\mathrm{Pt}_{3} \mathrm{Cu}$ at different simulation times a) $t=20 \mathrm{~ns}$ and c) at $\mathrm{t}=40 \mathrm{~ns}$. The corresponding size distributions are reported in graphs b) and d). Pt atoms are blue and $\mathrm{Cu}$ atoms tan. Argon atoms are not displayed for clarity.

\section{References}

[1] Coutanceau, C.; Baranton, S. "Advanced Processes in Catalytic Oxidation - Oxygen Activation in Fuel Cells and Electrocatalytic Processes", in "From Laboratory Studies to Industrial Applications", D. Duprez and F. Cavani (Eds.), Imperial College Press, London, 2012. [2] Nørskov, J. K.; Bligaard, T.; Rossmeisl, J.; Christensen, C. H. Towards the computational design of solid catalysts. Nature Chem., 2009, 1, 37-46

[3] Chen, S.; Gasteiger, H. A.; Hayakawac, K.; Tadac, T.; Shao-Horn, Y. Platinum-Alloy Cathode Catalyst Degradation in Proton Exchange Membrane Fuel Cells: Nanometer-Scale Compositional and Morphological Changes, J. Electrochem. Soc., 2010, 57, A82-A97 
[4] Greeley, J.; Stephens, I. E. L.; Bondarenko, A. S.; Johansson, T. P.; Hansen, H. A.; Jaramillo, T. F.; Rossmeisl, J.; Chorkendorff, I.; Nørskov, J. K. Alloys of platinum and early transition metals as oxygen reduction electrocatalysts, Nature Chemistry, 2009, 1, 552 - 556

[5] Wang, C.; Markovic, N. M.; Stamenkovic, V. R. Advanced Platinum Alloy Electrocatalysts for the Oxygen Reduction Reaction, ACS Catalysis, 2012, 2, 891-898

[6] Wu, J.; Qi, L.; You, H.; Gross, A.; Li, J.; Yang H. Icosahedral Platinum Alloy Nanocrystals with Enhanced Electrocatalytic Activities, J. Am. Chem. Soc., 2012, 134, 11880-11883

[7] Peng, Z.; Yang H. Designer platinum nanoparticles: Control of shape, composition in alloy, nanostructure and electrocatalytic property, Nano Today 2009, 4, 143-164

[8] Guo, S.; Wang, E. Noble metal nanomaterials: Controllable synthesis and application in fuel cells and analytical sensors, Nano Today $2011,6,240-264$

[9] Debe, M. K. Electrocatalyst approaches and challenges for automotive fuel cells, Nature, $2012,48643-51$

[10] Huang, X.; Zhao, Z.; Cao, L.; Chen, Y.; Zhu, E.; Lin, Z.; Li, M.; Yan, A.; Zettl, A.; Wang, Y. M. et al. High-performance transition metal-doped $\mathrm{Pt}_{3} \mathrm{Ni}$ octahedra for oxygen reduction reaction, Science, 2015, 348, 1230-1234.

[11] Paffet, M.T.; Beery, J.G.; Gottesfeld, S. Oxygen reduction at $\mathrm{Pt}_{0.65} \mathrm{Cr}_{0.35}, \mathrm{Pt}_{0.2} \mathrm{Cr}_{0.8}$ and roughened platinum. J. Electrochem. Soc. 1988, 135, 1431- 1436.

[12] Yang, H.; Coutanceau, C.; Léger, J. -M.; Alonso-Vante, N.; Lamy C. Methanol tolerant oxygen reduction on carbon-supported $\mathrm{Pt}-\mathrm{Ni}$ alloy nanoparticles. J. Electroanal. Chem. ,2005,576, 305-313.

[13] Koffi, R. C.; Coutanceau, C.; Garnier, E.; Léger, J. -M.; Lamy C. Synthesis, characterization and electrocatalytic behavior of non-alloyed $\mathrm{PtCr}$ methanol tolerant nanoelectrocatalysts for the oxygen reduction reaction (ORR). Electrochim. Acta, 2005, 50, 4117-4127. 
[14] Yu, X.; Ye, S. Recent advances in activity and durability enhancement of Pt/C catalytic cathode in PEMFC: Part II: Degradation mechanism and durability enhancement of carbon supported platinum catalyst, J. Power Sources, 2007, 172, 145-154

[15] Hernández-Fernández, P.; Rojas, S.; Ocón, P.; Fuente, J. L. G.; Fabián, J. S.; Sanza, J. M. A. Peña, Carcía-García, F. J.; Terreros, P.; Fierro, J. L. G. Influence of the Preparation Route of Bimetallic Pt-Au Nanoparticle Electrocatalysts for the Oxygen Reduction Reaction, J. Phys. Chem. C, 2007, 111, 2913 - 2923.

[16] Yancey, D. F.; Carino, E. V.; Crooks, R. M. Electrochemical Synthesis and Electrocatalytic Properties of Au@Pt Dendrimer-Encapsulated Nanoparticles, J. Am. Chem. Soc., 2010, 132, $10988-10989$.

[17] Zhang, J.; Sasaki, K.; Sutter, E.; Adzic, R. R. Stabilization of platinum oxygen-reduction electrocatalysts using gold clusters, Science, 2007, 315,220 - 222.

[18] Sasaki, K.; Naohara, H.; Cai, Y.; Choi, Y. M.; Liu, P.; Vukmirovic, M. B.; Wang, J. X.; Adzic, R. R. Core-Protected Platinum Monolayer Shell High-Stability Electrocatalysts for Fuel-Cell Cathodes, Angew. Chem. Int. Ed., 2010, 49, 8602 - 8607.

[19] V.Tripkovic, Hansen, H. A.; Rossmeisl, J.; Vegge, T. First principles investigation of the activity of thin film Pt, Pd and Au surface alloys for oxygen reduction, Phys. Chem. Chem. Phys., $2015,17,11647-11657$

[20] Brault, P.; Coutanceau, C.; Jennings, P. C.; Vegge, T.; Berndt, J.; Caillard, A.; Baranton, S.; Lankiang, S. Molecular dynamics simulations of ternary $\mathrm{Pt}_{\mathbf{x}} \mathrm{Pd}_{\mathrm{y}} \mathrm{Au}_{\mathrm{z}}$ fuel cell nanocatalyst growth, International Journal of Hydrogen Energy, 2016, 41, 22589-22597

[21] Lankiang, S.; Baranton, S.; Coutanceau, C. Electrocatalytic behaviour towards oxygen reduction reaction of carbon-supported $\mathrm{Pt}_{x} \mathrm{M}_{\mathrm{y}} \mathrm{Au}_{\mathrm{z}}(\mathrm{M}=\mathrm{Ni}, \mathrm{Cu}, \mathrm{Co})$ binary and ternary catalysts, Electrochimica Acta, 2017, 24, 2287-2299 
[22] Lankiang, S.; Chiwata, M.; Baranton, S.; Uchida, H.; Coutanceau, C. Oxygen Reduction Reaction at Binary and Ternary Nanocatalysts Based on Pt, Pd and Au, Electrochimica Acta 2015, 182, 131-142.

[23] Liu, F.; Sun, K.; Rui, Z.; Liu, J.; Juan, T.; Liu, R.; Luo, J.; Wang, Z.; Yao, Y.; Huang, L. et al. Highly Durable and Active Ternary Pt-Au-Ni, Electrocatalyst for Oxygen Reduction Reaction, ChemCatChem, 2018, 10, $3049-3056$

[24] Brault, P.; Neyts, E. Molecular dynamics simulations of supported metal nanocatalyst formation by plasma sputtering, Catalysis Today 2015, 256, 3-12

[25] Stamenkovic, V. R.; Fowler, B.; Mun, B. S.; Wang, G.; Ross, P. N.; Lucas, C. A.; Marković, N. M. Improved Oxygen Reduction Activity on $\mathrm{Pt}_{3} \mathrm{Ni}(111)$ via Increased Surface Site Availability, Science 2007, 315, 493-497

[26] Kim, M.; Lee, C.; Ko, S. M.; Nam, J.-M. Metal alloy hybrid nanoparticles with enhanced catalytic activities in fuel cell applications, Journal of Solid-State Chemistry, 2019, 27, 0295303

[27] Wu, J.; Zhang, J.; Peng, Z.; Yang, S.; Wagner, F. T.; Yang, H. Truncated Octahedral Pt ${ }_{3} \mathrm{Ni}$ Oxygen Reduction Reaction Electrocatalysts, J. American Chemical Society 2010, 132, 49844985

[28] Fortunelli, A.; Goddard III, W. A.; Sementa, L.; Barcaro, G.; Negreirosa, F. R.; JaramilloBotero, $\mathrm{A}$. The atomistic origin of the extraordinary oxygen reduction activity of $\mathrm{Pt}_{3} \mathrm{Ni}_{7}$ fuel cell catalysts, Chem. Sci., 2015, 6, 3915

[29] Wegner, K.; Piseri, P., Vahedi Tafreshi H.; Milani P. Cluster beam deposition: a tool for nanoscale science and technology. Journal of Physics D: Applied Physics, 2006, 39, R439-R459 
[30] Caillard, A.; Cuynet, S.; Lecas, T.; Andreazza, P.; Mikikian, M.; Thomann, A.-L.; Brault, P. PdPt catalyst synthesized using a gas aggregation source and magnetron sputtering for fuel cell electrodes. Journal of Physics D: Applied Physics, 2015, 48, 475302

[31] Quesnel, E.; Pauliac-Vaujour, E.; Muffato, V. Modeling metallic nanoparticle synthesis in a magnetron-based nanocluster source by gas condensation of a sputtered vapor. Journal of Applied Physics, 2010, 107, 054309

[32] Brault, P.; Chamorro-Coral, W.; Chuon, S.; Caillard, A.; Bauchire, J.-M.; Baranton, S.; Coutanceau, C.; Neyts, E. Molecular Dynamics simulations of initial Pd and PdO nanocluster growths in a magnetron gas aggregation source, Frontiers of Chemical Science and Engineering, 2019, DOI: 10.1007/s11705-019-1792-5, available online

[33] Chamorro-Coral, W.; Caillard, A.; Brault, P.; Andreazza, P.; Coutanceau, C.; Baranton, S. The Role of Oxygen on the Growth of Palladium Clusters Synthesized by Gas Aggregation Source, Plasma Processes and Polymers, 2019, DOI: 10.1002/ppap.201900006, available online

[34] Foiles, S.; Baskes, M.; Daw, M. Embedded-atom-method functions for the fcc metals Cu, $\mathrm{Ag}, \mathrm{Au}, \mathrm{Ni}, \mathrm{Pd}, \mathrm{Pt}$, and their alloys, Phys. Rev. B, 1986, 33, 7983-7991.

[35] Zhou, X. W.; Johnson, R. A.; Wadley, H. N. G. Misfit-energy-increasing dislocations in vapor-deposited CoFe/NiFe multilayers, Phys. Rev. B, 2004, 69, 144113

[36] Zhou, X. W. ; Wadley, H. N. G.; Johnson, R. A.; Larson, D. J.; Tabat, Cerezo, N. A.; PetfordLong, A. K. ; Smith, G. D. W.; Clifton, P. H.; Martens, R. L. et al., Atomic scale structure of sputtered metal multilayers, Acta mater. 2001, 49, 4005-4015

[37] Johnson, R. A. Alloy models with the embedded-atom method, Phys. Rev. B, 1989, 39, 12554-12559 
[38] Graves, D. B.; Brault, P. Molecular dynamics for low temperature plasma-surface interaction studies, J. Phys. D, 2009, 42, 194011

[39] Plimpton, S. Fast parallel algorithms for short-range molecular dynamics. Journal of Computational Physics, 1995, 117, 1-19

[40] http://lammps.sandia.gov/

[41] Humphrey, W.; Dalke, A.; Schulten, K., "VMD - Visual Molecular Dynamics", Journal of Molecular Graphics, 1996, 14, 33-38.

[42] http://www.ks.uiuc.edu/Research/vmd/

[43] Tyson, R.; Miller A. A., Surface free energies of solid metals: Estimation from liquid surface tension measurements, Surface Science, 1977, 62, 267-276

[44] Mattei, J. -G.; Grammatikopoulos, P.; Zhao, J.; Singh, V.; Vernieres, J.; Steinhauer, S.; Porkovich, A.; Danielson, E.; Nordlund, K.; Djurabekova, F. et al. Gas-Phase Synthesis of Trimetallic Nanoparticles. Chem. Mater., 2019, 31, 2151-2163.

[45] Okamoto, H. Ni-Pt (Nickel-Platinum). J. Phase Equil. Diff., 2010, 31, 32.

[46] Abe, T.; Sundman, B.; Onodera, H. Thermodynamic Assessment of the Cu-Pt System. J. Phase Equil. Diff. 27 (2006) 5-13.

[47] Ghosh, S. K.; Mandal, M.; Kundu, S.; Nath, S.; Pal, T. Bimetallic Pt-Ni nanoparticles can catalyze reduction of aromatic nitro compounds by sodium borohydride in aqueous solution. Appl. Catal. A, 2004, 268, 61-66.

[48] Varshney, M.; Sharma, A.; Shin, H. -J., Lee, H. H.; Jeon T. -Y.; Lee, B. -H.; Chae, K. -H.; Won, S. O. Influence of Ni doping on PtNi nanoparticles: Synthesis, electronic/atomic structure and photocatalyst investigations. J. Phys. Chem. Solids, 2017, 110, 187-194.

[49] Kang, Y.; Jiang, B.; Alothman, Z. A.; Badjah, A. Y.; Naushad, M.; Habila, M.; Wabaidur, S.; Henzie, Li, J. H.; Yamauchi, Y. Mesoporous PtCu Alloy Nanoparticles with Tunable 
Compositions and Particles Sizes Using Diblock Copolymer Micelle Templates. Chem. Eur. J. 25 (2019) $343-348$.

[50] Ozolinšs, V.; Wolverton, C.; Zunger, A. Cu-Au, Ag-Au, Cu-Ag and Ni-Au intermetallics: Firstprinciples study of phase diagrams and structures. Phys. Rev. B 57, (1998) $6427-6443$.

[51] Fedorov, P. P.; Volkov, S. N. Au-Cu Phase Diagram. Russian J. Inorg. Chem. 61 (2016) 772775.

[52] Sopoušek, J.; Kryštofová, A.; Premović, M.; Zobač, O.; Polsterová, S.; Broža, P.; Buršík, J. Au-Ni nanoparticles: Phase diagram prediction, synthesis, characterization, and thermal stability. CALPHAD 58 (2017) 25-33.

[53] Okamoto, H.; Massalski, T. B. The Au-Pt (Gold-Platinum) System. Bull. Alloy Phase Diagrams, 1985, 6, 46-56.

[54] Mihut, C.; Descorme, C.; Duprez, D.; Amiridis, M. D. Kinetic and Spectroscopic Characterization of Cluster-Derived Supported Pt-Au Catalysts. J. Catal., 2003, 212, 125-135. [55] Petkov, V.; Wanjala, B. N.; Loukrakpam, R.; Luo, J.; Yang, L.; Zhong, C.-J.; Shastri, S. Pt-Au Alloying at the Nanoscale, Nano Lett. 2012, 12, 4289-4299.

[56] Llamosa, D.; Ruano, M.; Martínez, L.; Mayoral, A.; Roman, E.; García-Hernández, M.; Huttel, Y. The ultimate step towards a tailored engineering of core@shell and core@shell@shell nanoparticles, Nanoscale, 2014, 6, 13483-13486.

[57] Hernández-Fernández, P.; Rojas, S.; Ocón, P.; Gómez de la Fuente, J. L.; San Fabián, J.; Sanza, J.; Penã, M. A.; Garclá-Garclá, F. J.; Terreros, P.; Fierro, J. L. G. Influence of the Preparation Route of Bimetallic Pt-Au Nanoparticle Electrocatalysts for the Oxygen Reduction Reaction. J. Phys. Chem. C, 2007, 111, 2913-2923.

[58] Xiao, S.; Hu, W.; Luo, W.; Wu, Y.; Li, X.; Deng, H. Size effect on alloying ability and phase stability of immiscible bimetallic nanoparticles. Eur. Phys. J. B, 2006, 54, 479-484. 
[59] Deng, L.; Hu, W.; Deng, H.; Xiao, S. Surface Segregation and Structural Features of Bimetallic Au-Pt Nanoparticles. J. Phys. Chem. C, 2010, 114, 11026-11032.

[60] Leppert, L.; Kummel, S. The Electronic Structure of Gold-Platinum Nanoparticles: Collecting Clues for Why They Are Special. J. Phys. Chem. C, 2011, 115, 6694-6702.

[61] Jennings, P. C.; Lysgaard, S.; Hansen, H. A.; Vegge, T. Decoupling strain and ligand effects in ternary nanoparticles for improved ORR electrocatalysis. Phys. Chem. Chem. Phys. 18 (2016) 24737-24745.

\section{Table of Content Graphic}

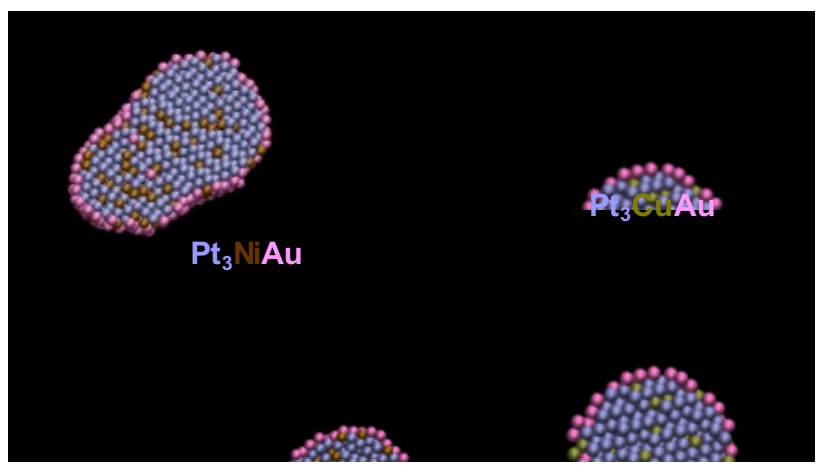

